\title{
Correlation between P Wave Dispersion, QRS Duration \& QT Dispersion in Hospital Events in Cases of Acute Coronary Syndrome
}

\author{
Mahmoud Fekry Hassan Hassebo, M.B. B.Ch \\ Visiting Resident, Faculty of Medicine, Department of Critical Care Medicine, Alexandria University
}

"Corresponding author: Mahmoud Fekry Hassan Hassebo, M.B. B.Ch, Visiting Resident, Faculty of Medicine, Department of Critical Care Medicine, Alexandria University, Hospitals University of Alexandria, Egypt, E-mail: mahmoudhassebo@yahoo.com

Received Date: $29^{\text {th }}$ October 2015

Accepted Date: $11^{\text {th }}$ February 2016

Published Date: $15^{\text {th }}$ February 2016
Citation: Hassebo MFH (2016) Correlation between P Wave Dispersion, QRS Duration \& QT Dispersion in Hospital Events in Cases of Acute Coronary Syndrome. Enliven: Clin Cardiol Res 3(S1): 001.

Copyright: @ 2016 Dr. Mahmoud Fekry Hassan Hassebo. This is an Open Access article published and distributed under the terms of the Creative Commons Attribution License, which permits unrestricted use, distribution and reproduction in any medium, provided the original author and source are credited.

\section{Thesis}

Submitted to Faculty of Medicine

Alexandria University

In Partial Fulfillment of the requirements for

Master Degree in Critical Care Medicine

\section{Thesis}

Published with

Enliven: Clinical Cardiology and Research

ISSN: $2375-7310$

\section{Supervisors}

\section{Prof. Dr. Tarek Hussein El Badawy}

Professor of Cardiology and Angiology

Faculty of Medicine

University of Alexandria

Dr. Mohamed Mostafa Abd El Salam Megahed

Assistant Professor of Critical Care Medicine

Faculty of Medicine

University of Alexandria
Prof. Dr. Muhammad Nasr eldin El Sayed

Professor of Critical Care Medicine

Alexandria University Hospitals
Submit your manuscript at

http://enlivenarchive.org/submit-manuscript.php

New initiative of Enliven Archive

Apart from providing HTML, PDF versions; we also provide video version and deposit the videos in about 15 freely accessible social network sites that promote videos which in turn will aid in rapid circulation of articles published with us. 